Diabetologia 11, 517-526(1975)

(C) by Springer-Verlag 1975

\title{
Glucagon and Insulin from Lean Rats and Genetically Obese Fatty Rats: Studies by Radioimmunoassay, Radioreceptorassay and Bioassay
}

\author{
M. Laburthe, F. Rançon, P. Freychet and G. Rosselin \\ Unité de Recherches de Diabétologie et d'Etudes Radio-Immunologiques des Hormones Protéiques, (Institut National de la Santé et de la \\ Recherche Médicale), Hôpital Saint-Antoine, Paris, France
}

Received: January 24, 1975, and in revised form: July 28, 1975

\begin{abstract}
Summary. Insulin, proinsulin and glucagon extracted from lean rat pancreases were studied in radioimmunoassay, radioreceptorassay and bioassay systems. Extracted insulin behaved identically to a rat insulin used as a reference standard in radioimmunoassay. On the basis of its immunoreactivity, extracted insulin was slightly less potent (about $70 \%$ ) than the rat standard insulin in competing with the binding of ${ }^{125} \mathrm{I}$-insulin to rat liver membranes (radioreceptorassay) and in stimulating glucose oxidation by rat fat cells (bioassay). Extracted glucagon and a pork glucagon used as a reference standard were indistinguishable in two radioimmunoassay systems for glucagon, in competing with the binding of ${ }^{125}$ I-glucagon to rat liver membranes (radioreceptorassay) and in stimulating adenylate cyclase in rat liver membranes (bioassay). Genetically obese rats (Zucker, "fatty") were compared to their lean littermates with respect to insulin, proinsulin and glucagon extracted from their
\end{abstract}

pancreases. Proinsulin represented the same proportion of total immunoreactive insulin in both types of rats. In the radioimmunoassays, the radioreceptorassays and the bioassays, insulin, proinsulin and glucagon from obese rats were indistinguishable from insulin, proinsulin and glucagon from lean rats. It is concluded that the pancreatic hormones of obese ("fatty") rats possess the same immunoreactivity and biological potency as those of nonobese rats. This excludes the possibility that some alteration in the biological properties of pancreas insulin and/or glucagon of fatty rats could explain the metabolic abnormalities observed in this type of obesity.

Key words: Insulin, glucagon, receptors, adenylate cyclase, radioreceptorassay, bioassay, radioimmunoassay, liver membranes, fat cells, genetically obese rat (fatty).
Most of the studies that have been performed during the past decade on pancreatic hormones have used radioimmunoassay systems. However, the antigenic determinants in the insulin $[1,2]$ and glucagon $[3,4]$ molecules are often not related to the biological activity of the hormone. The method recently developed for the study of both insulin $[5,6]$ and glucagon [7] - receptor interactions have, provided a means by which the bioactive structure of the hormone can be investigated directly.

In the present report we have compared the results obtained with the radioimmunoassay and the radioreceptorassay methods in assaying the insulin and glucagon extracted from the pancreas. We have also used bioassays and radioreceptorassays to analyze the biological properties of insulin and glucagon of genetically obese (fatty) rats [8] and of their lean controls to see whether this type of obesity could be related to a structural alteration of the insulin or glucagon molecules.

\section{Materials and Methods}

\section{Animals}

Twenty week-old genetically obese (fa/fa) Zucker rats [8] and their lean controls (FA/-) were obtained from the "Centre d'Elevage du C. N. R. S." (45-Orléans la Source, France). Animals were fed a commercial pelleted diet (U. A. R., BO 3, Villemoisson s/Orge, France) ad libitum. Animals were anaesthetized with ether and blood was collected from the inferior vena cava in a $10 \mathrm{ml}$ syringe rinsed with heparin, containing Kallikrein inhibitor (Zymophren, Spécia), $2500 \mathrm{~K} \mathrm{I} \mathrm{U} / \mathrm{ml}$ of blood, and immediately centrifuged at $4^{\circ} \mathrm{C}$. Plasmas were stored at $-20^{\circ} \mathrm{C}$ until assayed.

\section{Hormones}

The following were used as standards and for iodination in radioimmunoassays and radioreceptorassays: rat insulin (18 I U/mg, Dr. A. Lambert); rat proinsulin (Dr. D. F. Steiner); porcine insulin (monocomponent, MCS-970, 27.2 I U/mg, Dr. J. Schlichtkrull); porcine proinsulin (Dr. R. E. Chance) and porcine glucagon (lot B $66 \mathrm{~K} 1070$, Dr. J. Schlichtkrull).

\section{Extraction and Fractionation of the Hormones}

Insulin and glucagon were extracted from pooled pancreases according to Kenny [9], with modifications described elsewhere [10]. Powdered pancreatic extracts $(100 \mathrm{mg})$ were dissolved in $3 \mathrm{M}$ acetic acid and 
submitted to gel filtration on a $2.5 \times 140 \mathrm{~cm}$ column of Sephadex G-50 (Pharmacia) equilibrated and eluted with $1 \mathrm{M}$ acetic acid, $\mathrm{pH} 2.4$, at a flow rate of 0.3 $\mathrm{ml} / \mathrm{min} / \mathrm{cm}^{2}$. Fractions of $5 \mathrm{ml}$ were collected, pooled and lyophilized in the presence of $4 \mathrm{mg}$ of bovine serum albumin (BSA, Fraction V - Pentex) per fraction. Lyophilized powders were dissolved in Krebs Ringer phosphate (KRP) buffer, $\mathrm{pH} 7.5$, for insulin

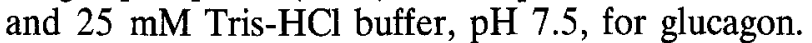
Further dilutions were done in the same buffers containing $10 \mathrm{mg} / \mathrm{mlBSA}$. Under these conditions the $\mathrm{pH}$ of the solutions was not altered (7.5). The column had been calibrated with ${ }^{125} \mathrm{I}$-porcine proinsulin $(260$ $\mu \mathrm{Ci} / \mu \mathrm{g}),{ }^{131} \mathrm{I}$-human insulin $(330 \mu \mathrm{Ci} / \mu \mathrm{g})$ and ${ }^{125} \mathrm{I}-$ porcine glucagon $(600 \mu \mathrm{Ci} / \mu \mathrm{g})$.

\section{Radioimmunoassays}

Radioimmunoassays [11] were performed in conditions described elsewhere for insulin [12] and for glucagon [13]. Guinea pig anti-human insulin and rabbit anti-porcine glucagon $(\mathrm{K})$ were obtained in this laboratory. The rabbit anti-porcine glucacon (K 47), specific for pancreatic glucagon [14], was a gift of $\mathrm{L}$. Heding. Iodinated human insulin was prepared by the "Centre National de Transfusion Sanguine, Paris". Monoiodinated porcine glucagon [15] was used in the radioimmunoassays. The separation of free and antibody-bound insulin or glucagon was performed by adsorption of the free antigen to silicate [16].

\section{Binding to Membrane Receptors (Radioreceptor- assays)}

The binding assays of insulin $[6,17,18]$ and glucagon [19] were carried out with mono ${ }^{125}$ I-insulin [5] and mono ${ }^{125}$ I-glucagon [15] and with purified or partially purified liver plasma membranes [20] prepared from $100-150 \mathrm{~g}$ Sprague-Dawley rats. The following modifications were introduced in order to improve the sensitivity of the assay ${ }^{1}$. Liver membranes were incubated with hormone in two sequential steps [21]. For insulin, incubations were carried out at $4^{\circ} \mathrm{C}$ in KRP buffer, $\mathrm{pH} 7.5$, containing $14 \mathrm{mg} / \mathrm{ml} \mathrm{BSA}$ (Fraction V - Pentex) and $1 \mathrm{mM} \mathrm{N}$ ethyl maleimide as inhibitor of insulin degradation [22], in a final volume of $250 \mu \mathrm{l}$. In the first step, varying concentrations of unlabelled insulin (or unknown samples) were incubated with purified plasma membranes [step 15 in ref. 20] for 8 hrs. The second step started with the addition of ${ }^{125} \mathrm{I}$ insulin at about $0.8 \mathrm{ng} / \mathrm{ml}$ to each tube and incubation was continued for $16 \mathrm{hrs}$. For glucagon, the first step

\footnotetext{
1 P. Freychet, unpublished results.
}

consisted of incubating varying concentrations of unlabelled glucagon (or unknown samples) with partially purified [step 11 in ref. 20] plasma membranes for 30 $\min$ at $30^{\circ} \mathrm{C}$. The second step was initiated with the addition of ${ }^{125} \mathrm{I}$-glucagon at $0.9 \mathrm{ng} / \mathrm{ml}$ to each tube and incubation was continued for $2 \mathrm{hrs}$ at $22^{\circ} \mathrm{C}$. The KRP buffer, pH 7.5, contained BSA at $26 \mathrm{mg} / \mathrm{ml}$, Zymophren at $2500 \mathrm{~K} \mathrm{IU} / \mathrm{ml}$ and Bacitracin at $110 \mu \mathrm{g} / \mathrm{ml}$ as inhibitor of glucagon degradation $[19,23]$. For both hormones, membranes were used at $0.2-0.3 \mathrm{mg}$ membrane protein $[24] / \mathrm{ml}$ incubation medium. Both of the radioreceptorassays can detect unlabelled hormone at $0.5 \mathrm{ng} / \mathrm{ml}$ incubation medium [21].

\section{Measurement of Biological Activity}

Stimulation of adenylate cyclase activity by glucagon in rat liver plasma membranes was measured as described previously [25]. Biological activity of insulin and proinsulin was measured as the stimulation of glucose oxidation by isolated rat fat cells [26]. Fat cells were prepared from epididymal fat pads [27] obtained from 100-150 g Sprague-Dawley rats and incubated with glucose- $U-{ }^{14} \mathrm{C}$ as described elsewhere [26].

\section{Expression of Results and Statistical Analysis}

Data from radioimmunoassays and from radioreceptorassays were expressed as the percentage of initial binding $\left(\frac{\mathrm{B}}{\mathrm{BO}} \times 100\right.$ where Bo represents the binding of ${ }^{125} \mathrm{I}$-hormone in the absence of unlabelled hormone). The logit transformation of this percentage $\left(\operatorname{logit} y=\log \frac{\mathrm{y}}{100-\mathrm{y}}\right.$, where $\left.\mathrm{y}=\frac{\mathrm{B}}{\mathrm{Bo}} \times 100\right)$ is plotted against the logarithm of the concentration of unlabelled hormone. In the bioassays, the production of ${ }^{14} \mathrm{Co}_{2}$ or of $3^{\prime}, 5^{\prime}$, cyclic AMP (cAMP) are expressed as the percentage of increase above the basal level ( $\left.\frac{\text { observed production - basal level }}{\text { basal level }} \times 100\right)$ and plotted against the logarithm of the hormone concentration. The regression lines were calculated by the method of the least squares. The significance of the difference between the slopes and between the y intercepts of paired regression lines was calculated by Student's t-test.

\section{Results}

\section{A-Assays of Pancreatic Hormones from Lean Rats}

Fig. 1 (bottom) gives the elution pattern of hormones extracted from pancreas of lean rats. 



Fig. 1. Gel filtration patterns of immunoreactive insulin (IRI) and of immunoreactive glucagon (IRG) extracts from obese rat pancreases (top) and of lean rat pancreases (bottom). Other details are indicated in Materials and Methods. The void volume (Vo) is indicated by the absorbancy of proteins at $280 \mathrm{~m} \mu$. The dotted lines represented the elution profiles of the ${ }^{125}$ I-proinsulin (PRO), ${ }^{131}$ I-insulin (INS) and ${ }^{125} \mathrm{I}$-glucagon (GLU) used as markers

\section{I - Insulin and Proinsulin-Like Fraction (PLF) ${ }^{1}$}

Radioimmunoassay. Extracted insulin followed the same dilution curve as rat insulin as indicated by the identity of the slopes of their regression lines (Fig. 2, top). Likewise, the slopes of the regression lines of

\footnotetext{
1 Proinsulin-like-fraction (PLF) refers to proinsulin and proinsulin-like components which cannot be separated by this fractionation procedure.
}

extracted PLF and of rat insulin were significantly different (Fig. 2, bottom). Thus both extracted insulin and PLF can be evaluated in terms of immunoreactive insulin (IRI) by reference to the rat insulin. The equivalence between rat insulin and proinsulin was also tested with rat proinsulin. On a molar basis, 2.2 times as much proinsulin as insulin was required to inhibit the binding of ${ }^{125} \mathrm{I}$-insulin to antibody to the same extent. Thus the concentration of extracted PLF 

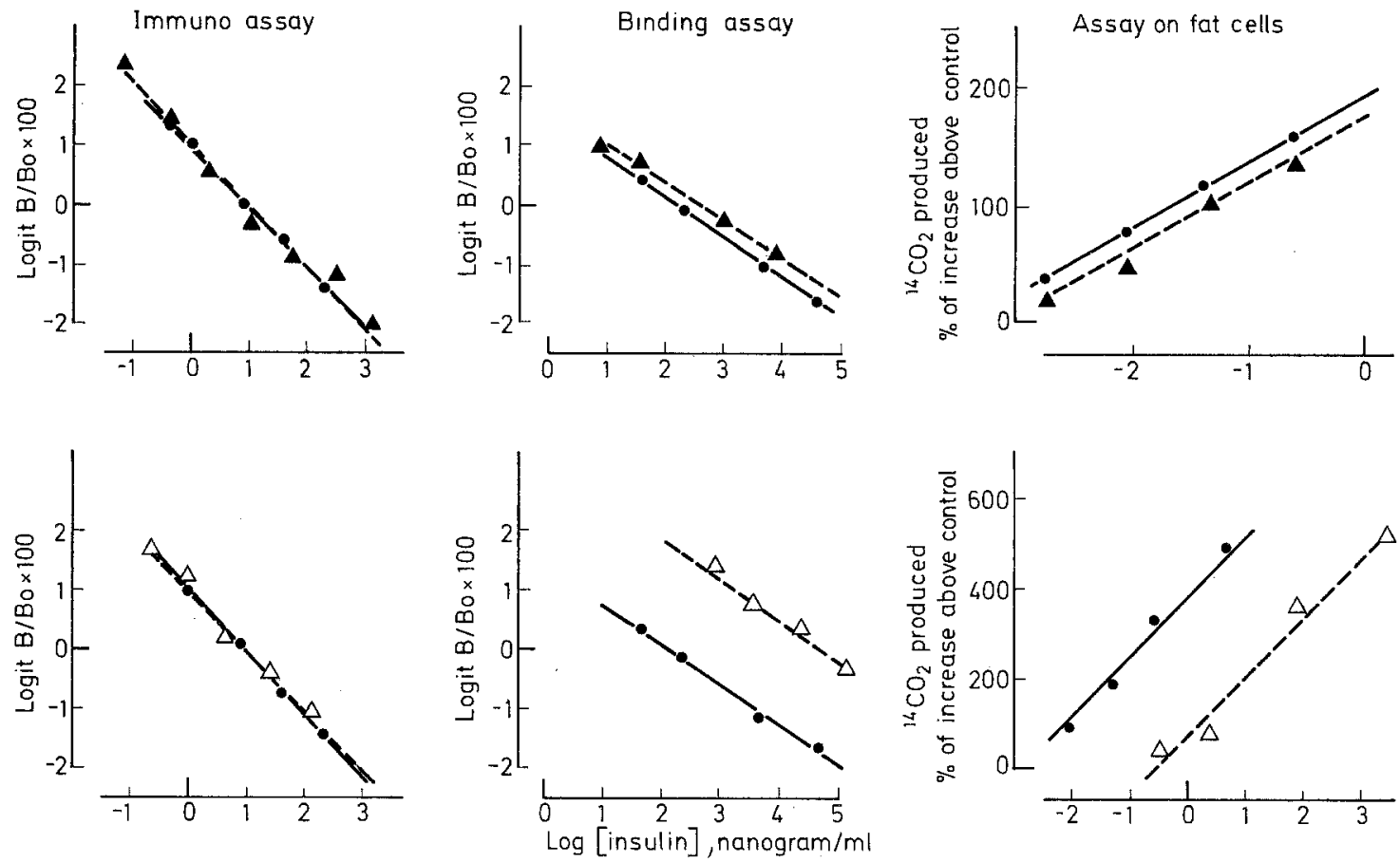

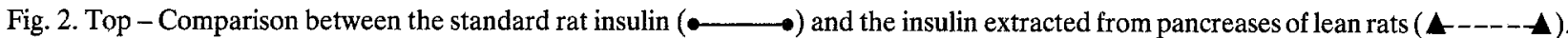
The regression lines and correlation coefficients were as follows. Radioimmunoassay: $y=-1.062 x, r=-0.999(p<0.001)$ for the standard insulin and $y=-1.007 x, r=-0.995(p<0.001)$ for the extracted insulin. Radioreceptorassay: $y=-0.662 x+1.375, r=$ $-0.999(\mathrm{p}<0.001)$ for the standard insulin and $\mathrm{y}=-0.635 \mathrm{x}+1.595, \mathrm{r}=-0.993(\mathrm{p}<0.01)$ for the extracted insulin. Bioassay: $y=$ $55.387 \mathrm{x}+192.753, \mathrm{r}=0.999(\mathrm{p}<0.001)$ for the standard insulin and $\mathrm{y}=57.564 \mathrm{x}+176.589, \mathrm{r}=0.985(\mathrm{p}<0.01)$ for the extracted insulin. Bottom - Comparison between the standard rat insulin $(\bullet \longrightarrow)$ and the PLF extracted from pancreases of lean rats $\triangle----\triangle$ ). The regression lines and correlation coefficients for standard insulin in the radioimmunoassay and in the radioreceptorassay were as indicated above. Those for extracted PLF were as follows: Radioimmunoassay: $y=-0.910 \mathrm{x}, \mathrm{r}=-0.988$ ( $\mathrm{p}<0.001$ ). Radioreceptorassay: $y=-0.752 x+3.452, r=-0.994(p<0.01$ ). Bioassay (fat cells): $y=133.485 x+386.747, r=0.987$ ( $<<0.01$ ) for.the standard insulin and $\mathrm{y}=125.797 \mathrm{x}+74.841, \mathrm{r}=0.994(\mathrm{p}<0.01)$ for the extracted PLF. Each experimental point is the mean of triplicate determinations

is 2.2 times higher after calculation by reference to rat proinsulin than by reference to rat insulin.

Receptor - Binding Assay. Regression lines of extracted insulin and of rat insulin were parallel since their slopes did not differ significantly (Fig. 2, top). However, the $y$ intercept of extracted insulin was significantly higher $(p<0.02)$ than that of rat insulin. Half-inhibition of the initial binding of ${ }^{125}$ I-insulin required a higher concentration of extracted insulin $(12.2 \mathrm{ng} / \mathrm{ml})$ than of rat insulin $(8.2 \mathrm{ng} / \mathrm{ml})$. Thus extracted insulin is about 1.5 times less potent than rat insulin in competing with the binding of ${ }^{125} \mathrm{I}$-insulin to receptors. Standard insulin that had been added to a lyophilized fraction devoid of insulin, and serially diluted under the same conditions as extracted insulin, was quantitatively indistinguishable, in the receptor binding assay, from standard insulin directly added to the assay buffer. Thus, the difference observed between standard and extracted insulin cannot be accounted for by a "nonspecific" interference in the assay system.
The regression line for extracted PLF paralleled that of rat insulin (Fig. 2, bottom). However, the $y$ intercepts of extracted PLF and rat insulin differed significantly $(p<0.001)$. Half inhibition of the initial binding of ${ }^{125} \mathrm{I}$-insulin was obtained with about $100 \mathrm{ng}$ of IRI equivalent $/ \mathrm{ml}$, i. e., 12 times more than with rat insulin. Thus extracted PLF was about $8 \%$ as potent as rat insulin in displacing the ${ }^{125} \mathrm{I}$-insulin from its binding to liver membranes. This percentage was obtained by reference to the immunoreactivity of proinsulin in the insulin radioimmunoassay system; it decreased to about $4 \%$, on a molar basis, when the lower (approx. $50 \%$, see above) affinity of proinsulin to insulin antibody was taken into account.

Assay on Fat Cells. The dose responses of glucose oxidation in isolated fat cells (Fig. 2, top) were linear with rat insulin $(\mathrm{p}<0.001)$ and extracted insulin $(\mathrm{p}<$ $0.01)$. The slopes of the regression lines were not significantly different for the rat insulin and the extracted insulin. However the $y$ intercept of the extracted insulin was significantly lower $(p<0.05)$ than that 
of the rat insulin. Half-maximal stimulation was obtained with a higher concentration of extracted insulin $(0.27 \mathrm{ng} / \mathrm{ml})$ than of rat insulin $(0.19 \mathrm{ng} / \mathrm{ml})$. The ratio extracted insulin insulin

to produce half-maximal effect is

equal to 1.4 and is in good agreement with that observed in the radioreceptorassay (i. e., 1.5).

The slope of the regression lines of extracted PLF and of rat insulin did not differ significantly (Fig. 2, bottom). However, their y intercepts were significantly different $(\mathrm{p}<0.001)$ and extracted PLF was only $10 \%$ as potent as rat insulin in stimulating glucose oxidation. This percentage decreased to about $5 \%$, on a molar basis, when extracted PLF was expressed in terms of rat proinsulin instead of IRI equivalents. This weak bioactivity of PLF compares well with its low binding affinity ( $4 \%$ that of insulin) to the insulin receptors.
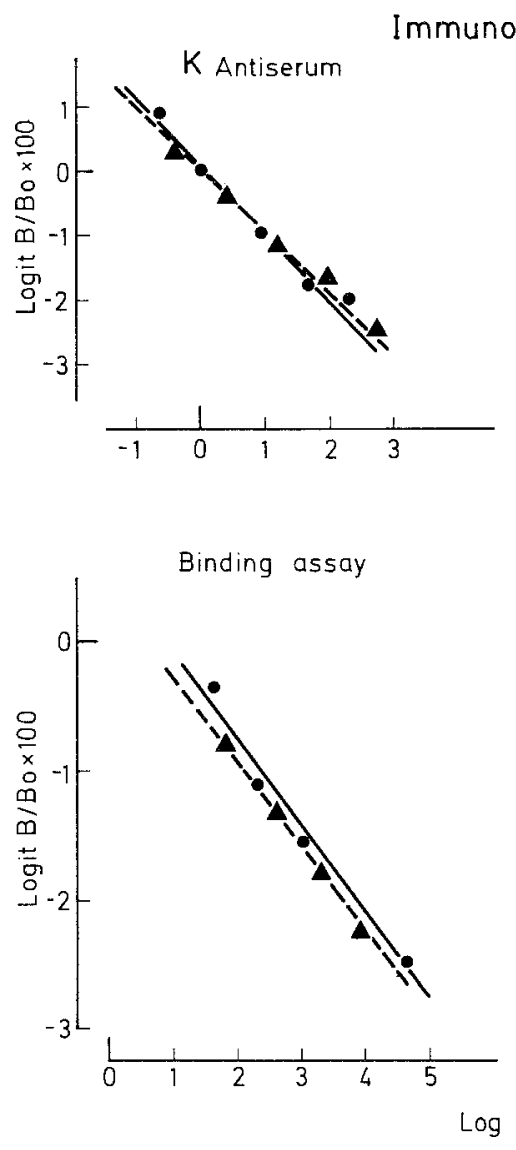

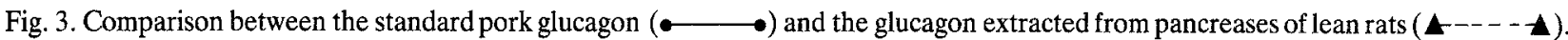
Equations of the regression lines and correlation coefficients were as follows: Radioimmunoassay with antiserum K: $y=-0.984 x, r$ $=-0.986(\mathrm{p}<0.001)$ for the standard glucagon and $\mathrm{y}=-0.853 \mathrm{x}, \mathrm{r}=-0.998(\mathrm{p}<0.001)$ for the extracted glucagon. Radioreceptorassay $y=-0.690 x+0.628, r=-0.989(p<0.01)$ for the standard glucagon and $y=-0.673 x+0.373, r=-0.999(p<0.02)$ for the extracted glucagon. Bioassay: $y=144.124 x+164.216, r=0.998(p<0.001)$ for the standard glucagon and $y=152.477 x+$ $37.454, r=0.960(p<0.01)$ for the extracted glucagon. Each point is the mean of triplicate determinations
Radioimmunoassay. The slopes of the regression lines of extracted glucagon and of pork glucagon were not significantly different with the two immune sera used (Fig. 3, top). Thus extracted glucagon gave the same dilution curves as pork glucagon in these two systems. In agreement with previous data [28], the two antisera produced the same result in measuring the glucagon content of pancreas.

Receptor-Binding Assay. The logit transformation of the data gave a significant regression line with pork glucagon $(\mathrm{p}<0.01)$ and with extracted glucagon $(\mathrm{p}<$ 0.01 ) within a range of $3-150 \mathrm{ng} / \mathrm{ml}$ (Fig. 3, bottom). The slopes and the $y$ intercepts of the two regression lines did not differ significantly. Thus extracted glucagon was as potent as pork glucagon in displacing the ${ }^{125}$ I-glucagon from its binding to liver plasma membranes.
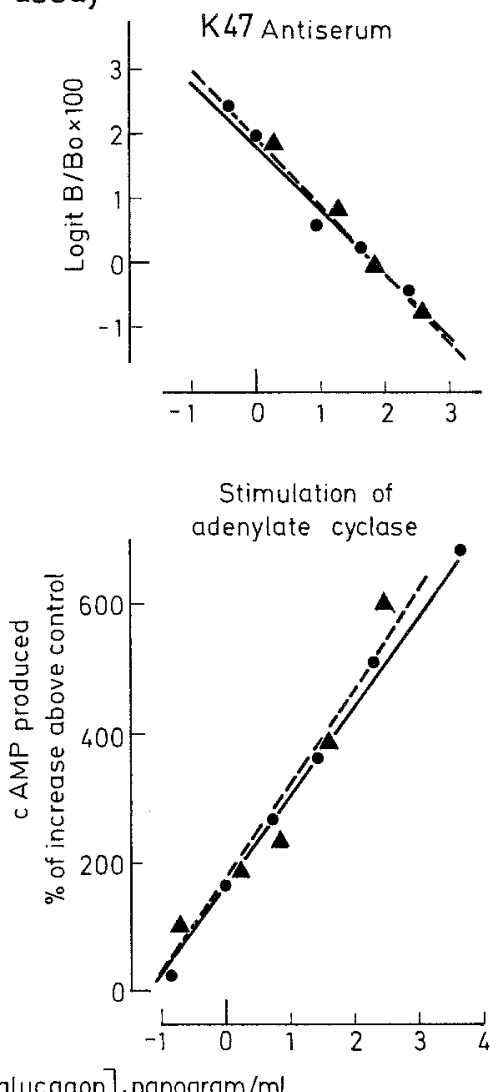
Stimulation of Adenylate Cyclase. When the glucagon concentration is plotted on a logarithmic scale, the dose response of cyclic AMP production was linear (Fig. 3, bottom) with pork glucagon $(p<0.001)$ and with extracted glucagon $(\mathrm{p}<0.01)$. The slopes and the $y$ intercepts of their regression lines were not significantly different. Thus extracted glucagon and pork glucagon had the same potency in stimulating the adenylate cyclase activity of rat liver plasma membranes. Comparison of maximal accumulation of cAMP revealed that both materials also had similar efficacy.

\section{$B$ - Properties of Insulin and Glucagon from Obese and Lean Rats}

\section{I - Biological Parameters}

Body weights of the 20 week-old obese rats were about twice those of controls (Table 1). The plasma insulin level was about 7 times higher and the pancreas insulin content 3 times higher in the obese than in the lean rats. However, rats from both groups showed similar plasma glucose level, plasma glucagon-likeimmunoreactivity (GLI), and pancreas glucagon content.

Table 1. Biological data from genetically obese rats and their lean controls

\begin{tabular}{lcc}
\hline & Obese & Lean \\
\hline Animal number & 12 & 11 \\
Body weight & $511 \pm 18$ & $269 \pm 16$ \\
Plasma Insulin $(\mu \mathrm{U} / \mathrm{ml})$ & $260 \pm 4$ & $36 \pm 3$ \\
Plasma Glucagon $(\mathrm{ng} / \mathrm{ml})$ & $0.38 \pm 0.12$ & $0.32 \pm 0.18$ \\
Plasma Glucose $(\mathrm{mg} / 100 \mathrm{mI})$ & $117 \pm 3$ & $112 \pm 2$ \\
Pancreas Insulin $(\mathrm{U} / \mathrm{g})^{\mathrm{a}}$ & $3.90 \pm 0.09$ & $139 \pm 0.02$ \\
${\text { Pancreas Glucagon }(\mu \mathrm{g} / \mathrm{g})^{\mathrm{a}}}$ & $7.95 \pm 0.15$ & $6.95 \pm 0.38$ \\
\hline
\end{tabular}

Except for the body weights, all values are the mean of triplicate determinations on pooled pancreases or plasmas $\pm S E M$.

a Values are expressed as Units of insulin or $\mu \mathrm{g}$ of glucagon per gram of wet weight of pancreas.
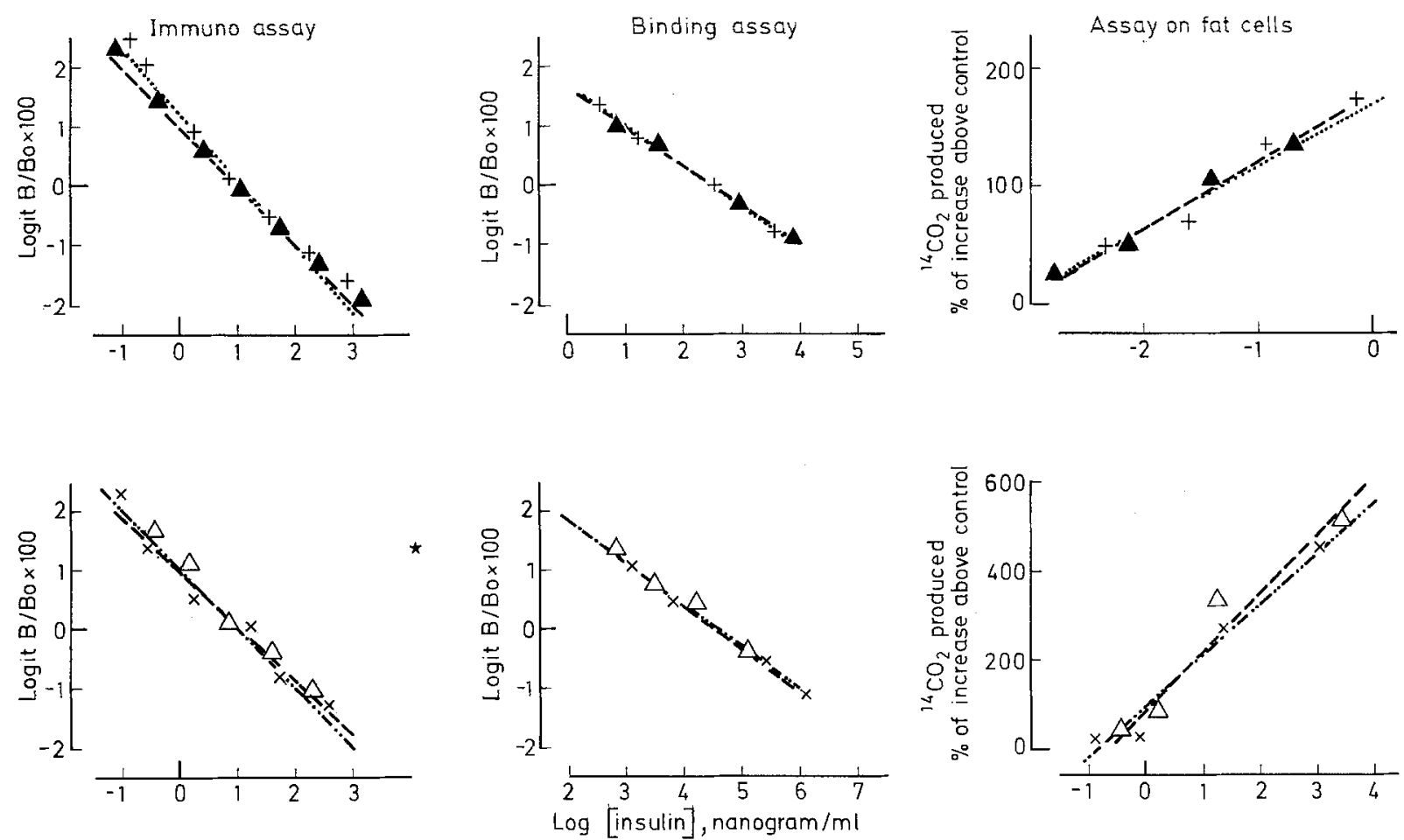

Fig. 4. Top - Comparison between the insulin extracted from obese rat pancreas $(+\cdots \cdots+)$ and the insulin extracted from lean rats pancreas ( legend to fig. 2 (top). Those for insulin from obese rats were as follows: Radioimmunoassay: $y=-1.131 \mathrm{x}, \mathrm{r}=-0.984$ ( $\mathrm{p}<0.001$ ). Radioreceptorassay: $y=-0.711 x+1.762, r=-0.999(p<0.001)$. Bioassay: $y=52.698 x+169.272, r=0.980(p<0.01)$ BottomComparison between the PLF extracted from obese rat pancreases $(X-\cdot-\cdot x)$ and the PLF extracted from lean rat pancreases $(\triangle---\triangle)$. Equations of the regression lines and correlation coefficients for PLF from lean rats were as indicated in the legends to fig. 2, (bottom). Those for PLF from obese rats were as follows: Radioimmunoassay: $y=-0.975 x, r=-0.992(p<0.001)$. Radioreceptorassay: $\mathrm{y}=0.723 \mathrm{x}+3.303, \mathrm{r}=-0.994(\mathrm{p}<0.01)$. Bioassay: $\mathrm{y}=120.873 \mathrm{x}+84.089, \mathrm{r}=0.991(<0.01)$. Each experimental point is the mean of triplicate determinations 


\section{II - Insulin and Proinsulin-Like Fraction (PLF)}

Gel Filtration. Two peaks of IRI were observed after gel filtration of the pancreatic extracts from obese rats (Fig. 1, top). A minor peak was eluted slightly ahead of the ${ }^{125} \mathrm{I}$-proinsulin marker and is referred to as the proinsulin-like fraction (PLF). The major peak, which is referred to as the insulin fraction, was eluted ahead of the ${ }^{131}$ I-insulin marker. Besides these two peaks, some IRI was found in the void volume, accounting for only $0.09 \%$ of total IRI (not shown in the figure). This gel filtration pattern was similar to that observed with extracts from lean rats (Fig. 1, bottom).

Radioimmunoassay. Insulin from obese rats had the same dilution curve as insulin from controls (Fig. 4, top) and as rat insulin, since the logit transformation of the data showed no significant difference between the slopes of their regression lines. Likewise, PLF from obese and lean rats followed the same dilution curve (Fig. 4, bottom) since the slopes of their regression lines did not differ significantly. Insulin and PLF from obese and from lean rats could be measured in terms of IRI equivalents by reference to rat insulin. The percentage of PLF in the pancreas of obese and lean rats was similar: $2.2 \%$ and $2.0 \%$ of total IRI, respectively. When this percentage was calculated on a molar basis by reference to rat proinsulin, it was $4.8 \%$ and $4.4 \%$ for obese rats and lean rats, respectively.

Receptor - Binding Assay. The regression line of insulin from obese rats was identical to that from controls, since their slopes and y intercepts did not differ significantly (Fig. 4, top). Thus, insulin from obese rats was as potent as insulin from controls in competing with the binding of ${ }^{125} \mathrm{I}$-insulin. Likewise the slopes and the $y$ intercepts of the regression lines of PLF from obese and lean rats were not significantly different (Fig. 4, bottom). PLF from obese or from
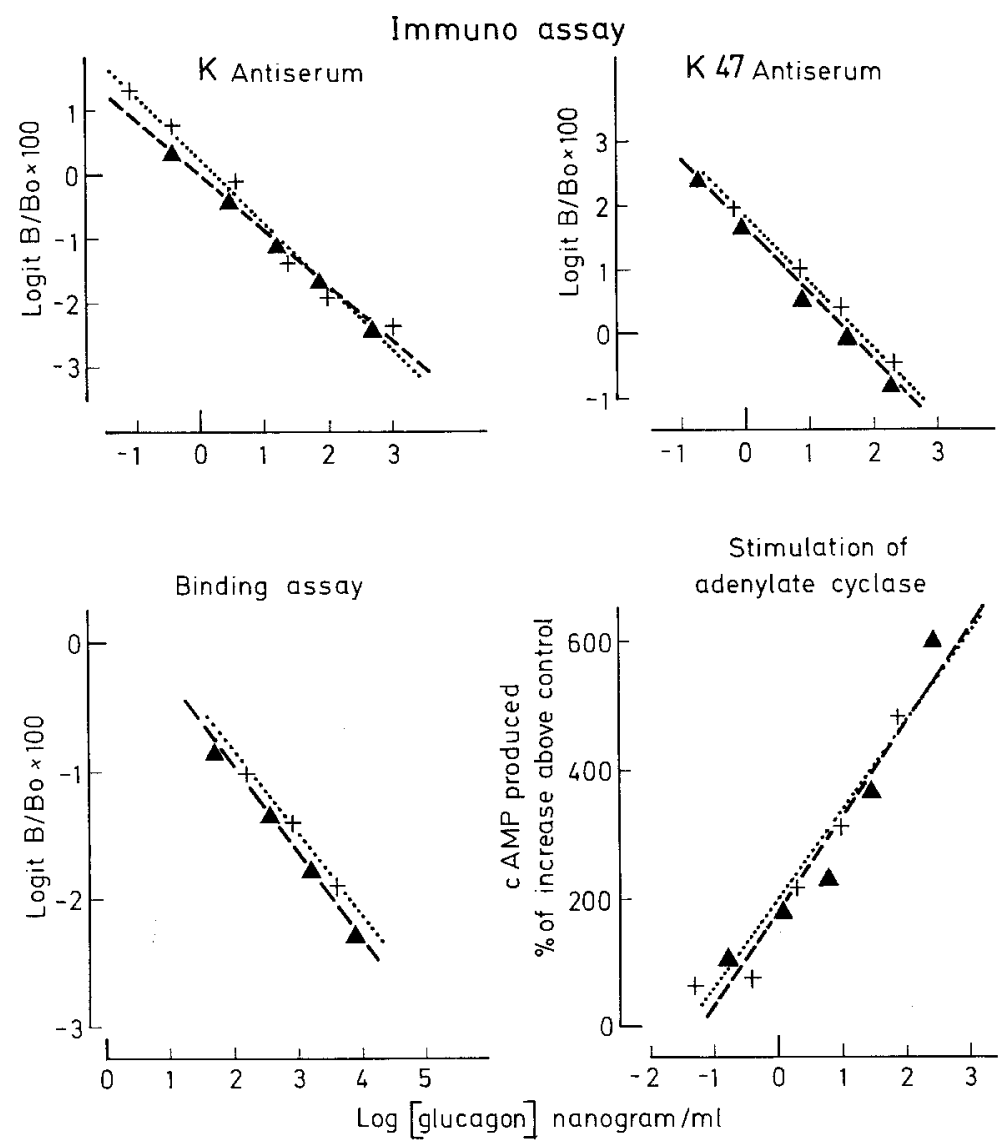

Fig. 5. Comparison between the glucagon extracted from obese rat pancreases $(+\ldots++)$ and the glucagon extracted from lean rat pancreases $(\mathbf{A}---\mathbf{A})$. Equations of the regression lines for glucagon from lean rats were indicated in the legend to fig. 3 . Those for glucagon extracted from obese rat pancreases were as follows: Radioimmunoassay with antiserum $\mathrm{K}: \mathrm{y}=-1.042 \mathrm{x}, \mathrm{r}=-0.989$ ( $\mathrm{p}<$ $0.001)$. Radioimmunoassay with antiserum $\mathrm{K} 47: \mathrm{y}=-1.055 \mathrm{x}, \mathrm{r}=-0.992(\mathrm{p}<0.01)$. Radioreceptorassay: $\mathrm{y}=-0.659 \mathrm{x}+0.509, \mathrm{r}$ $=-0.999(\mathrm{p}<0.01)$. Bioassay: $\mathrm{y}=136.625 \mathrm{x}+194.535, \mathrm{r}=0.969(\mathrm{p}<0.01)$. Each experimental point is the mean of triplicate determinations 
lean rats exhibited $5.5 \%$ of the potency of their insulin on a molar basis.

Assay on Fat Cells. The slopes and the y intercepts of the regression lines of insulin from obese and lean rats did not differ significantly (Fig. 4, top), indicating that insulin from obese rats is as potent as insulin from lean rats in stimulating glucose oxidation by isolated rat fat cells. The slopes and the y intercepts of PLF from obese and lean rats were identical (Fig. 4, bottom). PLF from obese and from lean rats exhibited about $6 \%$ of the potency of their insulin, on a molar basis. These results agree well with the lower ability of proinsulin to bind to liver plasma membranes and they confirmed previous observations $[6,17]$ that the reduced biological potency of proinsulin can be entirely accounted for by a reduced binding affinity.

\section{III - Glucagon}

Gel Filtration. Immunoreactive glucagon (IRG) of pancreatic extracts from lean rats eluted as a major peak coincident with the ${ }^{125}$ I-glucagon marker (Fig. 1, bottom). Small amounts of IRG, detected in the void volume and ahead of the main peak, accounted for only $0.4 \%$ and $1.1 \%$ of total IRG, respectively. A similar elution pattern was observed with the pancreatic extract from obese rats (Fig. 1, top).

Comparative Studies of Glucagon from Obese and Lean Rats. The slopes of the regression lines of glucagon from obese and from lean rats did not differ significantly regardless of the antiserum ( $K$ or $K 47$ ) used (Fig. 5, top). Nor were there any differences between glucagon from either origin, whether in the receptor - binding assay or in the stimulation of the adenylate cyclase (Fig. 5, bottom).

\section{Discussion}

The present studies confirm that the values found by radioimmunoassay are not necessarily related to the actual concentration of biologically active hormone. Thus, rat proinsulin which is half as potent as insulin with the antibody used, is 20-25 times less potent than insulin in the radioreceptorassay and in the bioassay. These results are similar to those observed in studies of proinsulin interactions with insulin receptors in rat liver membranes [17] and in studies of biological activity $[17,29,30]$ and binding affinity [31] of proinsulin in isolated rat fat cells.

Insulin extracted from the pancreases of lean rats was relatively less effective in the radioreceptorassay and in the bioassay than in the radioimmunoassay. This could be due to overestimation of the concentra- tion of the extracted insulin, possibly related to the presence of some component which would be more immunoreactive than the standard insulin used as reference [32]. Another explanation is that the extracted insulin contains molecules that are immunologically active, but which have lost their biological activity. Desalanine - desasparagine - insulin, which is probably eluted coincidently with insulin on gel filtration, has only $1.5 \%$ of the bioactivity of native insulin, but retains about $15 \%$ of the immunological reactivity with an anti-insulin antibody [6]. It cannot be ruled out that the extraction procedure employed may have modified the insulin as compared to the extraction procedure used in the preparation of the standard rat insulin. Whatever the explanation, the difference observed between the extracted insulin and the reference insulin emphasizes the need to study insulins that have undergone similar extraction procedures when comparing hormones extracted from animals in different states.

Glucagon extracted from rat pancreas behaved identically to porcine glucagon in radioimmunoassay, radioreceptorassay and bioassay. This could be expected since rat and pork glucagon have the same aminoacid composition [33] and also indicates that the extraction procedure used in the present study does not alter the glucagon molecule.

Recent studies have suggested that the insulin resistance observed in obesity may be related to a decrease in the number of insulin receptors $[34,35]$. Studies of insulin-receptor interactions in isolated hepatocytes from $\mathrm{fa} / \mathrm{fa}$ rats indicate that there is only a slight decrease in the number of insulin receptors and this is mainly observed in the fasting state ${ }^{1}$. An alternative explanation for the insulin resistance in fatty rats is that the proportion and/or the properties of endogenous proinsulin and insulin components are altered in such a way that the bioactivity of total endogenous insulin is decreased. Our data show that the percentage of proinsulin in the pancreas of obese and lean rats is similar. Thus, the modifications of pancreatic islets in the Zucker rat, which are consistent with a hyperfunction of the B-cell [36], are not associated with a modification of the proinsulin/insulin ratio. Furthermore, neither insulin nor proinsulin from obese and lean rats show any difference in all three assay systems. Since the amino acid sequences explored by these assays are distinct [6], this identity of response strongly supports the presence of identical insulin and proinsulin molecules in the pancreas of both types of rats. A difference related to a microheterogeneity of the insulin in obese and lean rats

\footnotetext{
${ }^{1}$ Broer, Y., Freychet, P., Rosselin, G.; unpublished data.
} 
cannot, however, be excluded. There are two insulins in the rat which differ by their charge [37] and which cannot be separated by standard gel filtration. However, the rat insulin used as standard is probably a mixture of the two insulins and it seems reasonable to assume that if there are some immunoreactive forms of insulin without biological activity, they are in the same proportion in the pancreases of obese and lean rats and are likely to react similarly in the three assay systems. Our results clearly indicate that insulin of obese $(\mathrm{fa} / \mathrm{fa})$ rats is as potent as insulin of lean rats. They extend to the Zucker rat similar observations made in other obese rodents (ob/ob mouse, New Zealand obese mouse and goldthioglucose-treated mouse) where no discrepancy was found between the immunoreactivity and the bioactivity of pancreas insulin [38]. Our data also exclude the possibility that the proinsulin or insulin component might behave as an antagonist of insulin since, with the proinsulin as well as with the insulin fraction from obese rats, there was an excellent agreement between the biological potency and the binding affinity.

The obesity of the Zucker rat is associated with high levels of free fatty acids [39], of triglycerides [40] and cholesterol [41]. Since glucagon inhibits the synthesis of triglycerides [42] and of free fatty acids in vivo [43] and in vitro [44], possibly through cAMP, it has been suggested that endogenous hyperlipemia might result from glucagon resistance [45]. Since the glucagon content of the obese rat pancreas is normal [46] and since the GLI content of plasma appears to be similar in obese and lean rats, hyperlipemia cannot be explained by a lack of glucagon. A possible cause of glucagon resistance would be the synthesis of biologically inactive - or less active - glucagon. This possibility is ruled out by the present study since glucagon of obese rats is indistinguishable from glucagon of lean rats in its capacity to bind to the glucagon receptors and to stimulate the adenylate cyclase.

\footnotetext{
Acknowledgements. In addition to those who gave us hormones or antiserum (see Methods), we thank: C. Boissard, A. M. Coudray and D. Hui Bon Hoa for their excellent technical assistance and D. Lhenry for her careful preparation of the manuscript. This work was supported by the Institut National de la Santé et de la Recherche Médicale (INSERM) and in part by grants from the Centre National de la Recherche Scientifique (CNRS) and the Délégation Générale de la Recherche Scientifique et Technique (DGRST).
}

\section{References}

1. Berson, S. A., Yalow, R. S.: Insulin in blood and insulin antibodies. Amer. J. Med. 40, 676-690 (1966)

2. Chance, R. E.: Chemical, physical, biological and immunological studies on porcine proinsulin and related peptides. In: Diab- etes (eds. R. R. Rodriguez, J. Vallance-Owen), pp. 292-305. Amsterdam: Excerpta Medica, I. C. S. n 231, 1 vol. 1971

3. Heding, L. G.: Immunological properties of pancreatic glucagon: antigenicity and antibody characteristics. In: Glucagon: molecular physiology, clinical and therapeutic implications. pp. 187-200. Oxford: Pergamon Press, 1 vol. 1972

4. Faloona, G. R.: The structure - function relationships of pancreatic glucagon. In: Glucagon: molecular physiology, clinical and therapeutic implications. pp. 201-204. Oxford: Pergamon Press, 1 vol. 1972

5. Freychet, P., Roth, J., Neville, D. M., Jr.: Monoiodoinsulin: demonstration of its biological activity and binding to fat cells and liver membranes. Biochem. biophys. Res. Commun. 43, 400-408 (1971)

6. Freychet, P., Roth, J., Neville, D. M., Jr: Insulin receptors in the liver: Specific binding of ${ }^{125}$ I-insulin to the plasma membrane and its relation to insulin bioactivity. Proc. nat. Acad. Sci. (Wash.) 68, 1833-1837 (1971)

7. Rodbell, M., Krans, M. J., Pohl, S. L., Birnbaumer, L.: The glucagon sensitive adenyl cyclase system in plasma membranes of rat liver. III Binding of glucagon: method of assay and specificity. J. biol. Chem. 246, 1861-1871 (1971)

8. Zucker, L. M., Zucker, T. G.: Fatty, a new mutation in the rat. J. Hered. 52, 275-278 (1961)

9. Kenny, A. J.: Extractable glucagon of human pancreas. J. clin. Endocr. 15, 1089-1105 (1955)

10. Rançon, F., Laburthe, M., Rosselin, G., Freychet, P.: Untractable hypoglycemia in an infant: studies on pancreas insulin and glucagon. Horm. Metab. Res. 6, 443-447 (1974)

11. Yalow, R. S., Berson, S. A.: Immunoassay of endogenous plasma insulin in man. J. clin. Invest. 39, 1157-1175 (1960)

12. Rosselin, G., Dolais, J.: Application de la méthode radio-immunologique au dosage de l'insuline humaine et au dosage de l'hormone folliculo-stimulante humaine (H FSH). Monographie ann. Sté Fse Biol. Clin. "Les Isotopes - Applications biocliniques", Expansion Sci. Ed. pp. 189-217. 1. Vol. 1967

13. Unger, R. H., Eisentraut, A. M., Mac Call, M. S., Madison, L. L.: Glucagon antibodies and an immunoassay for glucagon. $J$. clin. Invest. 40, 1280-1289 (1961)

14. Heding, L. G.: Radioimmunological determination of pancreatic and gut glucagon in plasma. Diabetologia 7, 10-19 (1970)

15. Nottey, J. J., Rosselin, G.: Monoiodoglucagon: préparation, isolement, identification, contrôle radio-immunologique. C. R. Acad. Sci. (Paris) 273, 2118-2121 (1971)

16. Rosselin, G., Assan, R., Yalow, R. S., Berson, S. A.: Separation of antibody - bound and unbound peptide hormones labeled with iodine 131 by talcum powder and precipitated silica. Nature (Lond.) 212, 355-357 (1966)

17. Freychet, P.: The interactions of proinsulin with insulin receptors on the plasma membrane of the liver. J. clin. Invest. 54, 1020-1031 (1974)

18. Freychet, P., Brandenburg, D., Wollmer, A.: Receptor - binding assay of chemically modified insulins. Diabetologia 10, 1-5 (1974)

19. Bataille, D., Freychet, P., Kitabgi, P., Rosselin, G.: Gut glucagon: a common receptor site with pancreatic glucagon in liver cell plasma membranes FEBS Letters 30, 215-218 (1973)

20. Neville, D. M., Jr: Isolation of an organ specific protein antigen from cell-surface membrane of rat liver. Biochim. biophys. Acta (Amst.) 154, 540-552 (1968)

21. Freychet, P.: Insulin receptors. In: Methods in receptor research (ed. M. Blecher), New York: Marcel Dekker Inc. (in press, 1975)

22. Freychet, P., Kahn, R., Roth, J., Neville, D. M., Jr: Insulin interactions with liver plasma membranes. Independence of 
binding of the hormone and its degradation. J. biol. Chem. 247, 3953-3961 (1972)

23. Desbuquois, B., Krug, F., Cuatrecasas, P.: Inhibitors of glucagon inactivation. Effect on glucagon - receptor interactions and glucagon - stimulated adenylate cyclase activity in liver cell membranes. Biochim. biophys. Acta (Amst.) 343, 101-120 (1974)

24. Lowry, O. H., Rosebrough, N. J., Farr, A. L., Randall, R. J.: Protein measurement with the Folin phenol reagent. J. biol. Chem. 193, 265-275 (1951)

25. Rosselin, G., Freychet, P.: Basal and hormone - stimulated adenylate cyclase in liver plasma membranes: Measurement by radioimmunoassay of cyclic AMP. Biochim. biophys. Acta (Amst.) 304, 541-551 (1973)

26. Simon, J., Freychet, P., Rosselin, G.: Chicken insulin: radioimmunological characterization and enhanced activity in rat fat cells and liver plasma membranes. Endocrinology 95, 1439-1449 (1974)

27. Rodbell, M.: Metabolism of isolated fat cells. I. Effects of hormones on glucose metabolism and lipolysis. J. biol. Chem. 239, 375-380 (1964)

28. Jarrousse, C., Rançon, F., Rosselin, G.: Hormonogénèse périnatale de l'insuline et du glucagon chez le rat. C. R. Acad. Sci. (Paris) 276, 585-588 (1973)

29. Kitabchi, A.: The biological and immunological properties of pork and beef insulin, proinsulin and connecting peptide. J. clin. Invest. 49, 979-987 (1970)

30. Gliemann, J., Sorensen, H. H.: Assay of insulin-like activity by the isolated fat cell method. IV. The biological activity of proinsulin. Diabetologia 6, 499-504 (1970)

31. Gammeltoft, S., Gliemann, J.: Binding and degradation of ${ }^{125} \mathrm{I}-$ insulin by isolated rat fat cells. Biochim. biophys. Acta (Amst.) 320, 16-32 (1973)

32. Soeldner, J. J., Sawin, C. T., Silbert, C. K., Mitchell, M. L.: Differences in immunologic activity among preparations of human insulin. Metabolism 23, 209-214 (1973)

33. Sundby, F., Markussen, J.: Isolation, crystallization and amino acid composition of rat glucagon. Horm. Metab. Res. 3, 184-187 (1971)

34. Freychet, P., Laudat, M. H., Laudat, P., Rosselin, G., Kahn, C. R., Gorden, P., Roth, J.: Impairment of insulin binding to the fat cell plasma membrane in the obese hyperglycemic mouse. FEBS Letters 25, 339-342 (1972)

35. Kahn, C. R., Neville, D. M., Jr, Roth, J.: Insulin - receptor interaction in the obese hyperglycemic mouse. A model of insulin resistance. J. biol. Chem. 248, 244-250 (1973)
36. Shino, A., Matsuo, T., Iwatsuka, H., Suzuoki, Z.: Structural changes of pancreatic islets in genetically obese rats. Diabetologia 9, 413-421 (1973)

37. Smith, L. F.: Species variation in the amino acid sequence of insulin. Amer. J. Med. 40, 662-666 (1966)

38. Stauffacher, W., Lambert, A. E., Vecchio, D., Renold A. E.: Measurements of insulin activities in pancreas and serum of mice with spontaneous ("obese" and "New Zealand obese") and induced (gold-thioglucose) obesity and hyperglycemia, with considerations on the pathogenesis of the spontaneous syndrome. Diabetologia 3, 230-237 (1967)

39. Zucker, L. M.: Hereditary obesity in the rat associated with hyperlipemia. Ann. N. Y. Acad. Sci. 131, 447-458 (1965)

40. Barry, N. S., Bray, G. A.: Plasma triglycerides in genetically obese rats. Metabolism 18, 833-839 (1969)

41. Zucker, T. F., Zucker, L. M.: Hereditary obesity in the rat associated with high serum fat and cholesterol. Proc. Soc. exp. Biol. (N. Y.) 110, 165-171 (1962)

42. Vaughan, M., Steinberg, D., Pittman, R.: On the interpretation of studies measuring uptake and esterification of $\mathrm{I}-{ }^{14} \mathrm{C}$ palmitic acid by rat adipose tissue in vitro. Biochim. biophys. Acta (Amst.) 84, 154-166 (1964)

43. Meikle, A. W., Klain, G. F., Hannon, J.P.: Inhibition of glucose oxidation and fatty acid synthesis in liver slices from fed, fasted and fasted-refed rats by glucagon epinephrine and cyclic adenosine-3', 5' -monophosphate. Proc. Soc. exp. Biol. (N. Y.) 143, 379-381 (1973)

44. Klain, G. J., Weiser, P. C.: Changes in hepatic fatty acid synthesis following glucagon injections in vivo. Biochem. biophys. Res. Commun. 55, 76-83 (1973)

45. Eaton, R. P., Shade, D. S.: Glucagon resistance as a hormonal basis for endogenous hyperlipemia. Lancet 1973 I, 973-974

46. Lemonnier, D., Aubert, R., Suquet, J. P., Rosselin, G.: Metabolism of genetically obese rats on normal or high-fat diet. Diabetologia 10, 697-701 (1974)

M. Laburthe, M. Sci. Institut National de la Santé et de la Recherche Médicale Batiment I. N. S. E. R. M. Hôpital Saint-Antoine 184, Rue de Faubourg Saint Antoine F-88571 Paris/Cedex 12 France 